\title{
Azospirillum canadense sp. nov., a nitrogen-fixing bacterium isolated from corn rhizosphere
}

Correspondence

George Lazarovits

lazarovitsg@agr.gc.ca

\author{
Samina Mehnaz, Brian Weselowski and George Lazarovits \\ Southern Crop Protection and Food Research Centre, Agriculture and Agri-Food Canada, \\ 1391 Sandford Street, London, Ontario N5V4T3, Canada
}

\begin{abstract}
A free-living diazotrophic strain, $\mathrm{DS} 2^{\top}$, was isolated from corn rhizosphere. Polyphasic taxonomy was performed including morphological characterization, Biolog analysis, and 16S rRNA, cpn60 and nifH gene sequence analyses. 16S rRNA gene sequence analysis indicated that strain DS2 ${ }^{\top}$ was closely related to the genus Azospirillum (96\% similarity). Chemotaxonomic characteristics (DNA G + C content 67.9 mol\%; Q-10 quinone system; major fatty acid $18: 1 \omega 7 \mathrm{c}$ ) were also similar to those of the genus Azospirillum. In all the analyses, including phenotypic characterization using Biolog analysis and comparison of cellular fatty acids, this isolate was found to be different from the closely related species Azospirillum lipoferum, Azospirillum oryzae and Azospirillum brasilense. On the basis of these results, a novel species is proposed for this nitrogen-fixing strain. The name Azospirillum canadense sp. nov. is suggested with the type strain $\operatorname{DS}^{\top}\left(=\right.$ NCCB $100108^{\top}=$ LMG $\left.23617^{\top}\right)$.
\end{abstract}

The genus Azospirillum was first described by Tarrand et al. (1978) with two species, Azospirillum lipoferum and Azospirillum brasilense. At present the genus comprises nine species, including, in addition to A. lipoferum and $A$. brasilense, Azospirillum amazonense (Magalhães et al., 1983), Azospirillum halopraeferens (Reinhold et al., 1987), Azospirillum irakense (Khammas et al., 1989), Azospirillum largimobile (Ben Dekhil et al., 1997), Azospirillum doebereinerae (Eckert et al., 2001), Azospirillum oryzae (Xie \& Yokota, 2005) and Azospirillum melinis (Peng et al., 2006). A few Azospirillum strains including A. brasilense and A. oryzae were isolated from rhizosphere of corn, growing in Western Ontario, Canada. Strain DS2 ${ }^{\mathrm{T}}$ was isolated from rhizosphere soil. It was identified as Azospirillum due to its cell shape, colony morphology, nitrogen fixation and $96 \%$ similarity for the 16S rRNA gene sequence but the species was not identified as it did not show close similarity to any known species of this genus. Strain $\mathrm{DS} 2^{\mathrm{T}}$ was screened for its growth-promoting activity and it showed significant growth promotion in two corn varieties and vegetables, under greenhouse conditions. This strain is on field trial for growth promotion in corn at two research stations in Ontario, Canada. In the present study, we characterized this strain by using a polyphasic approach, including phylogenetic analyses of the $16 \mathrm{~S}$ rRNA, cpn60 and nifH gene sequences.

Isolate $\mathrm{DS} 2^{\mathrm{T}}$ was isolated on $\mathrm{M}$ medium (Xie \& Yokota, 2005) except that biotin was not added and pH 7.2-7.4 was used. Subcultivation was done on the same medium at $30^{\circ} \mathrm{C}$

The GenBank/EMBL/DDBJ accession numbers for the 16S rRNA, cpn60 and nifH gene sequences of strain DS2 ${ }^{\top}$ are DO393891, DQ914833 and DQ393890, respectively. for $48-72 \mathrm{~h}$. The bacterium formed wet, white colonies which later turned light-pink. Cell morphology was observed using a scanning electron microscope. Cells of the bacterium were short rods $0.9 \mu \mathrm{m}$ in width and 1.8-2.5 $\mu \mathrm{m}$ in length, with a single polar flagellum (Fig. 1). Bacterial growth at different temperatures $\left(20-41{ }^{\circ} \mathrm{C}\right)$ and $\mathrm{pH}$ values $(4-10)$ and with various $\mathrm{NaCl}$ concentration $(0.5-3 \%)$ ranges was determined in $\mathrm{M}$ medium. The Biolog analysis system and API 20NE bacterial identification kit were used for physiological characterization. Results of the analyses are given in the species description. A summary of the results of carbon-source utilization suitable for the differentiation of isolate DS2 $2^{\mathrm{T}}$ from known Azospirillum species is presented in Table 1. Phosphate solubilization on NBRIP medium (Nautiyal, 1999) was not observed. Indole acetic acid production in the presence of $100 \mathrm{mg} \mathrm{l}^{-1}$ tryptophan in CCM (Rennie, 1981) was $\sim 6.5 \mu \mathrm{g} \mathrm{ml}^{-1}$.

Cellular fatty acid profiles of isolate $\mathrm{DS} 2^{\mathrm{T}}$, A. oryzae IAM $15130^{\mathrm{T}}$, A. lipoferum ATCC $29707^{\mathrm{T}}$ and A. brasilense ATCC $29145^{\mathrm{T}}$ were determined with a gas chromatograph, using the Sherlock Microbial Identification System (MIDI), according to a standard protocol (Paisley, 1996), and data are provided in Table 2 . The fatty acid profile of strain DS2 ${ }^{\mathrm{T}}$ was composed of $18: 1 \omega 7 c(54.9 \%), 16: 1 \omega 7 c(12.0 \%)$, $16: 0(12.3 \%)$ and $19: 0$ cyclo $\omega 8 c(0.9 \%)$; and hydroxy fatty acids $16: 03-\mathrm{OH}(2.2 \%)$ and $18: 12-\mathrm{OH}(2.2 \%)$. Fatty acids $12: 0(1.3 \%)$ and summed feature $6(1.5 \%)$ were detected in $\mathrm{DS}^{\mathrm{T}}$ but not in $A$. lipoferum, $A$. oryzae or $A$. brasilense. Its ratio for $18: 1 \omega 7 c$ is closest to that of $A$. lipoferum $(53.4 \%)$ but values for 19:0 cyclo $\omega 8 c, 16: 0$ 3-OH, 18:1 2-OH, $17: 1 \omega 8 c$ and $17: 1 \omega 6 c$ are almost two times lower than those of A. lipoferum (1.6, 4.3, 5.5, 3.4 and 


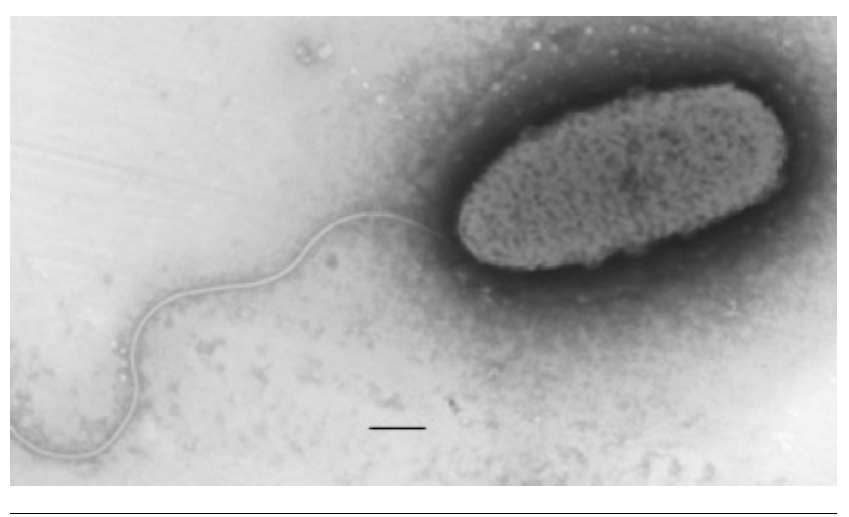

Fig. 1. Cell morphology of corn isolate $D S 2^{\top}$ observed under an electron microscope. Bar, $0.6 \mu \mathrm{m}$.

$7.1 \%)$. For fatty acids $14: 0,16: 0$ and $18: 0$, isolate $\mathrm{DS} 2^{\mathrm{T}}$ has threefold higher values than those for A. lipoferum. A. oryzae has similar a ratio to DS2 ${ }^{\mathrm{T}}$ for $19: 0$ cyclo $\omega 8 c(0.8 \%)$ and $18: 1 \omega 7 c(57.2 \%)$ but values for $16: 03-\mathrm{OH}(4.1 \%)$ and $18: 12-\mathrm{OH}(5.5 \%)$ are higher and values for $14: 0(0.7 \%)$, $16: 0(4.3 \%), 18: 0(0.5 \%), 17: 1 \omega 8 c(0.8 \%)$ and $17: 1 \omega 6 c$
(1.4\%) are two- to threefold lower than those of $\mathrm{DS}^{\mathrm{T}}$. $A$. brasilense has a very different profile from that of $A$. lipoferum, A. oryzae and isolate DS2 ${ }^{\mathrm{T}}$ and values for all the fatty acids used for comparison are either very high or very low compared to those for DS2 ${ }^{\mathrm{T}}$.

Determination of DNA base composition was carried out using the HPLC technique described by Mesbah et al. (1989). The DNA G+C content of strain $\mathrm{DS}^{\mathrm{T}}$ was $67.9 \mathrm{~mol} \%$, which is in accordance with values for the genus Azospirillum (64-71 mol\%; Ben Dekhil et al., 1997). The 16S rRNA gene was amplified by using the primers and PCR conditions previously described by Mehnaz et al. (2001). The sequence was deposited in GenBank (accession no. DQ393891). Phylogenetic analysis was performed using the software package Bionumerics (Applied Maths) after including the consensus sequence in an alignment of small ribosomal subunit sequences collected from the international nucleotide sequence library EMBL. The alignment was pairwise, calculated by using an open gap penalty of $100 \%$ and a unit gap penalty of $0 \%$. A similarity matrix was created by homology calculation with a gap penalty of $0 \%$ and after discarding unknown bases. A resulting tree based on comparison of 1475 bases was constructed using the

Table 1. Physiological differences between Azospirillum canadense sp. nov. isolate DS2 ${ }^{\top}$ and other Azospirillum species

Strains: 1 DS2 ${ }^{\mathrm{T}}$; 2, A. oryzae IAM $15130^{\mathrm{T}} ; 3$, A. lipoferum ATCC $29707^{\mathrm{T}} ; 4$, A. brasilense ATCC $29145^{\mathrm{T}}$; 5, A. dobereinerae; 6, A. largimobile; 7, A. halopraeferens; 8, A. irakense; 9, A. amazonense LMG $22237^{\mathrm{T}}$; 10, A. melinis TMCY $0552^{\mathrm{T}}$. +, Positive; - , negative; V, variable; ND, not determined. Data for $\mathrm{DS}^{\mathrm{T}}$, A. oryzae, A. lipoferum, A. brasilense and A. melinis are from this study. The remaining data were taken from Peng et al. (2006).

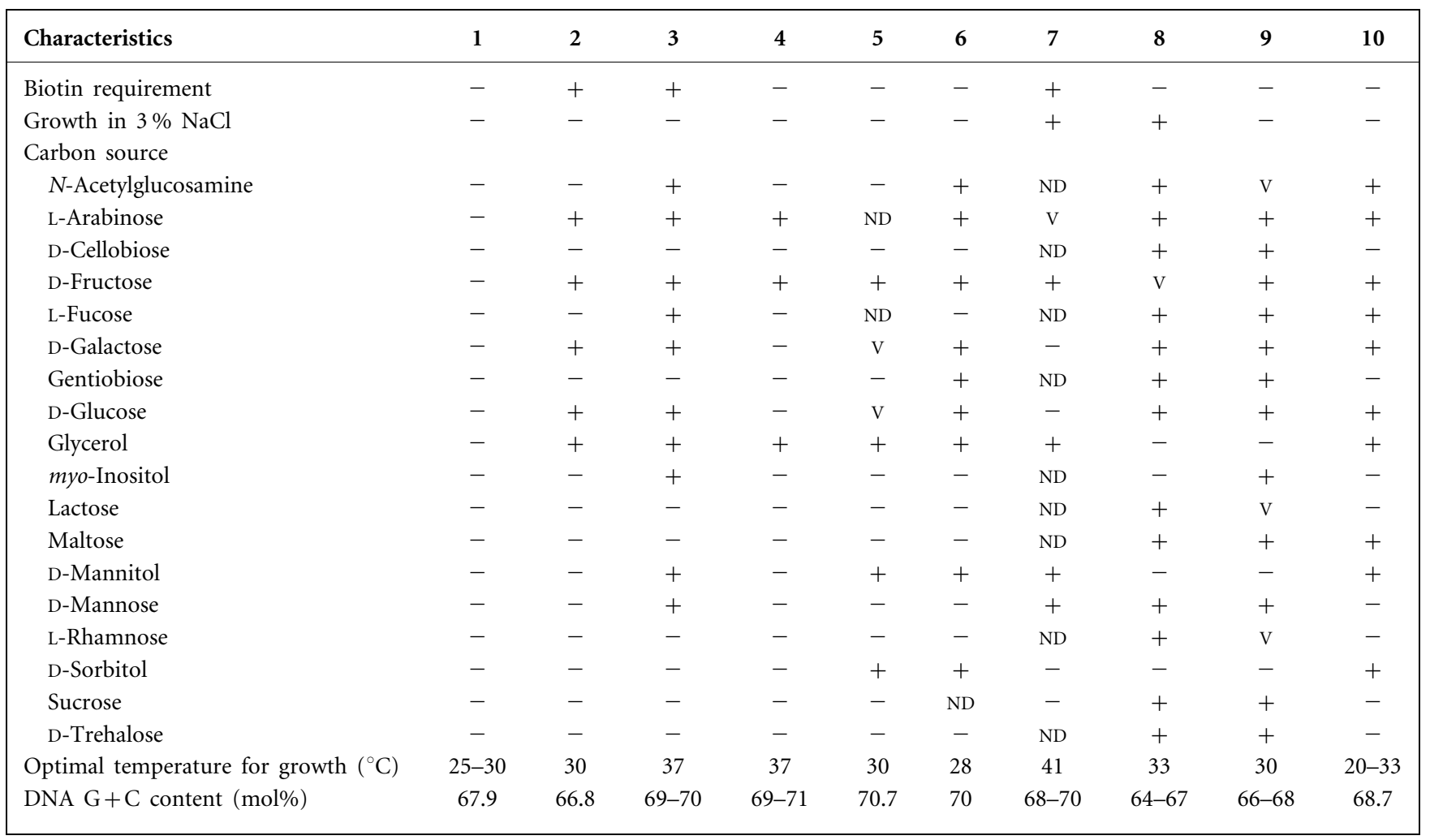


Table 2. Comparison of the cellular fatty acid content of corn rhizosphere isolate $D S 2^{\top}$ and related Azospirillum species

Data for all organisms are from this study. Fatty acid values are given as a percentage of the total peak area. Summed feature $1=13: 0$ 3-OH/15:1 isoH; summed feature 2=12:0 aldehyde?16:1 iso I/14:0 $3-\mathrm{OH}$; summed feature $3=16: 1 \omega 7 c / 16: 1 \omega 6 c$; summed feature $6=18: 0$ ante/18:2 $2 \omega 6,9 c$. ND, Not detected.

\begin{tabular}{|c|c|c|c|c|}
\hline Fatty acid & $\mathrm{DS}^{\mathrm{T}}$ & $\begin{array}{c}\text { A. oryzae } \\
\text { IAM } 15130^{\mathrm{T}}\end{array}$ & $\begin{array}{c}\text { A. lipoferum } \\
\text { ATCC } 29707^{\mathrm{T}}\end{array}$ & $\begin{array}{l}\text { A. brasilense } \\
\text { ATCC } 29145^{\mathrm{T}}\end{array}$ \\
\hline $13: 1$ at $12-13$ & ND & 0.6 & 0.7 & 0.3 \\
\hline $12: 0$ & 1.3 & ND & ND & ND \\
\hline $14: 0$ & 2.3 & 0.5 & 0.7 & 0.3 \\
\hline $15: 0$ & 1.3 & 0.5 & 1.4 & 0.2 \\
\hline $16: 0$ & 12.3 & 6.9 & 4.3 & 5.0 \\
\hline $17: 0$ & $\mathrm{ND}$ & 0.3 & 0.8 & 0.1 \\
\hline $18: 0$ & 2.2 & 0.7 & 0.5 & 0.2 \\
\hline $15: 03-\mathrm{OH}$ & ND & ND & 0.8 & 0.2 \\
\hline $16: 03-\mathrm{OH}$ & 2.2 & 4.1 & 4.3 & 3.2 \\
\hline $17: 03-\mathrm{OH}$ & ND & $\mathrm{ND}$ & 0.6 & $\mathrm{ND}$ \\
\hline $18: 03-\mathrm{OH}$ & ND & 0.5 & 0.5 & 0.1 \\
\hline $18: 12-\mathrm{OH}$ & 2.2 & 5.0 & 5.5 & 5.2 \\
\hline $15: 1 \omega 8 c$ & ND & ND & 0.6 & 0.1 \\
\hline $15: 1 \omega 6 c$ & ND & ND & 0.2 & ND \\
\hline $17: 1 \omega 8 c$ & 1.7 & 0.8 & 3.4 & 0.8 \\
\hline $17: 1 \omega 6 c$ & 2.8 & 1.4 & 7.1 & 1.5 \\
\hline $18: 1 \omega 7 c$ & 54.9 & 57.2 & 53.4 & 62.0 \\
\hline $19: 0$ cyclo $\omega 8 c$ & 0.9 & 0.8 & 1.6 & $\mathrm{ND}$ \\
\hline Summed feature 1 & ND & ND & 0.5 & ND \\
\hline Summed feature 2 & 0.7 & 5.3 & 5.9 & 4.7 \\
\hline Summed feature 3 & 12.0 & 14.6 & 6.5 & 14.9 \\
\hline Summed feature 6 & 1.5 & $\mathrm{ND}$ & $\mathrm{ND}$ & $\mathrm{ND}$ \\
\hline
\end{tabular}

neighbour-joining method. Bootstrap analysis was performed using the same software package to test the statistical reliability of the topology of the neighbour-joining tree with 1000 bootstrap resamples of the data. On the basis of distance matrix, the percentage $16 \mathrm{~S}$ rRNA gene sequence similarity indicated that the closest relatives to strain DS2 ${ }^{\mathrm{T}}$ are 'Roseomonas' genomospecies 6 ATCC $49961^{\mathrm{T}}(96.1 \%)$, A. oryzae IAM $15130^{\mathrm{T}}(95.9 \%)$, A. lipoferum ATCC $29707^{\mathrm{T}}$ (95.9\%) and A. brasilense $\mathrm{Sp} 7^{\mathrm{T}}$ (95.5\%). The phylogenetic tree based on 16S rRNA gene sequence, constructed by using the neighbour-joining method, is shown in Fig. 2.

A chaperonin gene (cpn60) was amplified from bacterial genomic DNA of isolate DS2 ${ }^{\mathrm{T}}$, A. lipoferum ATCC $29707^{\mathrm{T}}$, A. oryzae IAM $15130^{\mathrm{T}}$ and A. brasilense ATCC $29145^{\mathrm{T}}$ by using universal $c p n 60$ degenerate primers. The primers were H729, H730 (Hill et al., 2006), H1610 (5'-CGCCAGGGTTTTCCCAGTCACGACGAIIIIGCIGGYGACGGYACSACSAC-3') and H1611 (5'-AGCGGATAACAATTTCACACAGGACGRCGRTCRCCGAAGCCSGGIGCCTT-3'). For PCR, a primer mixture (forward mix 1 part $\mathrm{H} 729$ and 3 parts H1610; reverse mix 1 part $\mathrm{H} 730$ and 3 parts H1611) was used. The PCR conditions were $5 \mathrm{~min}$ at $94^{\circ} \mathrm{C}, 40$ cycles of $30 \mathrm{~s}$ at $94{ }^{\circ} \mathrm{C}, 30 \mathrm{~s}$ at $50{ }^{\circ} \mathrm{C}, 45 \mathrm{~s}$ at $72{ }^{\circ} \mathrm{C}$ and $5 \mathrm{~min}$ at $72{ }^{\circ} \mathrm{C}$. The DNA sequence of $\mathrm{DS} 2^{\mathrm{T}}$ showed $97.3 \%(539 /$ 554 identities), $93.6 \%$ (510/545 identities) and 83.2\% (445/ 535 identities) sequence similarity with cpn60 sequences of $A$. brasilense (accession no. DQ854727), A. lipoferum (accession no. DQ813650) and A. oryzae (accession no. DQ813649), respectively.

Semi-solid M medium was used for the acetylene reduction assay and it was carried out as described by Mehnaz \& Lazarovits (2006). Veil-like subsurface pellicle formation was observed and an ethylene peak was detected. The nifH gene was also amplified by PCR using the primer set PolF/ PolR and the conditions described by Poly et al. (2001). The expected 360 bp amplification product was observed. This PCR product was purified and sequenced. The sequence was deposited in GenBank (accession no. DQ393890). Comparison of the results through an NCBI BLAST search revealed highest sequence similarities with the nifH gene of A. lipoferum ATCC $29707^{\mathrm{T}}(95.4 \%)$, A. brasilense $\mathrm{Sp} 7^{\mathrm{T}}$ (94.8\%) and A. oryzae IAM $15130^{\mathrm{T}}$ (93.9\%). However, the similarities with the nifH gene of other diazotrophic bacteria were $89-91 \%$. 


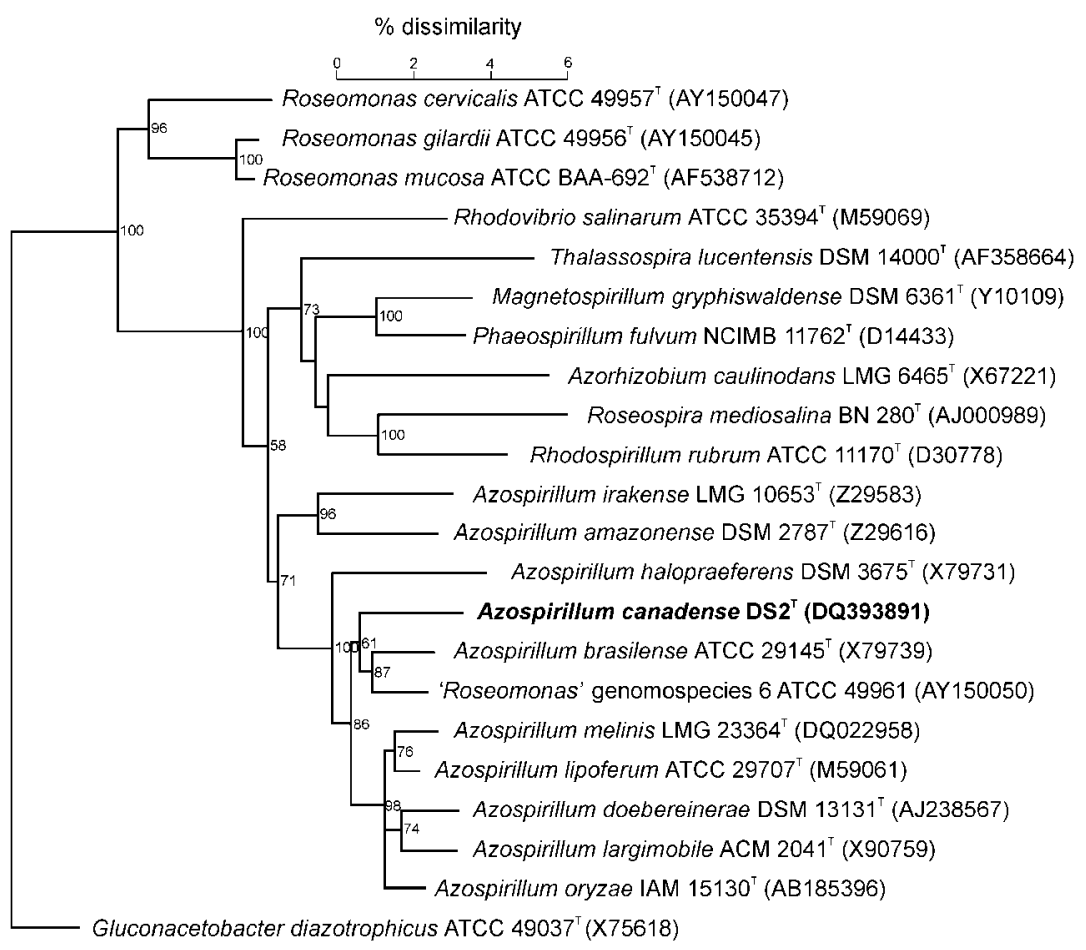

Fig. 2. Phylogenetic tree based on $16 \mathrm{~S}$ rRNA gene sequences, constructed by using the neighbour-joining method, showing close relationship between strain $\mathrm{DS}^{\top}$ and the nearest relatives of the genus Azospirillum. Numbers at nodes indicate percentages of occurrence in 1000 bootstrapped trees; only values greater than $60 \%$ are shown.

\section{Description of Azospirillum canadense sp. nov.}

Azospirillum canadense (can.ad.en'se. N.L. neut. adj. canadense pertaining to Canada, the region of isolation, referring to its isolation from Canadian soil).

Cells are short rods, $0.9 \times 1.8-2.5 \mu \mathrm{m}$ in size, Gramnegative, motile via a single polar flagellum. White to light-pink, rounded, wet colonies form after $48-72 \mathrm{~h}$. Growth occurs on $\mathrm{M}$ medium at $20-37^{\circ} \mathrm{C}$, pH 5-7 and $0.5-1 \% \mathrm{NaCl}$ concentration. Optimum temperature is $25-30^{\circ} \mathrm{C}$ and optimum $\mathrm{pH}$ is $5-7$. Positive for nitrogen fixation and indole acetic acid production; negative for phosphate solubilization. Malic acid, potassium gluconate, acetic acid, pyruvic acid methyl ester, succinic acid monomethyl ester, cis-aconitic acid, citric acid, formic acid, D-galacturonic acid, D-glucuronic acid, $\alpha$ and $\beta$ hydroxybutyric acid, $\alpha$-ketoglutaric acid, DL-lactic acid, malonic acid, propionic acid, quinic acid, D-saccharic acid, succinic acid, bromosuccinic acid, succinamic acid, Dalanine, $\mathrm{L}$-asparagine and $\mathrm{L}$-aspartic acid can be use as single carbon source. Sucrose, D-glucose, L-arabinose, D-arabitol, D-cellobiose, L-erythritol, D-fructose, L-fucose, D-galactose, gentiobiose, myo-inositol, D-lactose, D-mannose, D-mannitol, maltose, D-melibiose, D-raffinose, L-rhamnose, Dsorbitol, D-trehalose, xylitol, D-gluconic acid, $\alpha$-ketobutyric acid, L-alanine, L-glutamic acid, L-histidine, L-leucine, Lornithine, L-phenylalanine, L-proline, D-serine, L-serine, L-threonine, $\mathrm{N}$-acetyl D-glucosamine, trisodium acetate, capric acid, adipic acid and phenylacetic acid are not utilized. Positive for catalase, oxidase, nitrate reduction, $\beta$ glucosidase, $\beta$-galactosidase and acetoin production and negative for indole production, arginine dihydrolase, urease and gelatin hydrolysis. Biotin is not required for growth.
Major cellular fatty acids are $18: 1 \omega 7 c, 16: 1 \omega 7 c, 16: 0$. The DNA $\mathrm{G}+\mathrm{C}$ content is $67.9 \mathrm{~mol} \%$. The predominant quinone system is ubiquinone Q-10.

The type strain, $\operatorname{DS}^{\mathrm{T}}\left(=\right.$ NCCB $\left.100108^{\mathrm{T}}=\mathrm{LMG} 23617^{\mathrm{T}}\right)$, was isolated from rhizosphere of corn (Zea mays) from Delhi, Ontario, Canada.

\section{Acknowledgements}

We are thankful to Dr Peter Ashton, The University of York, UK, for bootstrap analysis, Ann Fook Yang, Agriculture and Agri-Food Canada, Ottawa, for electron microscopy and Dr Janet Hill, National Research Council Plant Biotechnology Institute, Saskatoon, Saskatchewan, Canada, for chaperonin sequence analysis. This work was supported by grants from Commercial Alcohols Inc., Brampton, Ontario and Agriculture and Agri-Food Canada MII Initiative.

\section{References}

Ben Dekhil, S., Cahill, M., Stackebrandt, E. \& Sly, L. I. (1997). Transfer of Conglomeromonas largomobilis subsp. largomobilis to the genus Azospirillum as Azospirillum largimobile comb. nov., and elevation of Conglomeromonas largomobilis subsp. parooensis to the new type species of Conglomeromonas, Conglomeromonas parooensis sp. nov. Syst Appl Microbiol 20, 72-77.

Eckert, B., Weber, O. B., Kirchhof, G., Halbritter, A., Stoffels, M. \& Hartmann, A. (2001). Azospirillum doebereinerae sp. nov., a nitrogen fixing bacterium associated with the C4-grass Miscanthus. Int J Syst Evol Microbiol 51, 17-26.

Hill, J. E., Paccagnella, A., Law, K., Melito, P. L., Woodward, D. L., Price, L., Leung, A. H., Ng, L., Hemmingsen, S. M. \& Goh, S. H. (2006). Identification of Campylobacter spp. and discrimination from Helicobacter and Arcobacter spp. by direct sequencing of PCR-amplified cpn60 sequences and comparison to cpnDB, a 
chaperonin reference sequence database. J Med Microbiol 55, 393-399.

Khammas, K. M., Ageron, E., Grimont, P. A. D. \& Kaiser, P. (1989). Azospirillum irakense sp. nov., a nitrogen fixing bacterium associated with rice roots and rhizosphere soil. Res Microbiol 140, 679-693.

Magalhães, F. M., Baldani, J. I., Souto, M., Kuykendall, J. R. \& Dobereiner, J. (1983). A new acid tolerant Azospirillum species. Ann Acad Bras Cienc 55, 417-430.

Mehnaz, S. \& Lazarovits, G. (2006). Inoculation effects of Pseudomonas putida, Gluconacetobacter azotocaptans and Azospirillum lipoferum on corn plant growth under green house conditions. Microb Ecol 51, 326-335.

Mehnaz, S., Mirza, M. S., Huarat, J., Bally, R., Normand, P. \& Malik, K. A. (2001). Isolation and $16 \mathrm{~S}$ rRNA sequence analysis of the beneficial bacteria from the rhizosphere of rice. Can J Microbiol 47, 110-117.

Mesbah, M., Premachandran, U. \& Whitman, W. B. (1989). Precise measurement of the $\mathrm{G}+\mathrm{C}$ content of deoxyribonucleic acid by high performance liquid chromatography. Int J Syst Bacteriol 39, 159-167.

Nautiyal, C. S. (1999). An efficient microbiological growth medium for screening phosphate solubilizing microorganisms. FEMS Microbiol Lett 170, 265-270.
Paisley, R. (1996). MIS Whole Cell Fatty Acid Analysis by Gas Chromatography Training Manual. Newark, DE: MIDI.

Peng, G., Wang, H., Zhang, G., Hou, W., Liu, Y., Wang, E. T. \& Tan, Z. (2006). Azospirillum melinis sp. nov., a group of diazotrophs isolated from tropical molasses grass. Int J Syst Evol Microbiol 56, 1263-1271.

Poly, F., Monrozier, L. J. \& Bally, R. (2001). Improvement in the RFLP procedure for studying the diversity of nifH genes in communities of nitrogen fixers in soil. Res Microbiol 152, 95-103.

Reinhold, B., Hurek, T., Fendrik, I., Pot, B., Gillis, M., Kersters, K., Thielemans, S. \& De Ley, J. (1987). Azospirillum halopraeferens sp. nov., a nitrogen fixing organism associated with roots of kallar grass (Leptochloa fusca (L.) Kunth). Int J Syst Bacteriol 37, 43-51.

Rennie, R. J. (1981). A single medium for the isolation of nitrogen fixing bacteria. Can J Microbiol 27, 8-14.

Tarrand, J. J., Kreig, N. R. \& Dobereiner, J. (1978). A taxonomic study of the Spirillum lipoferum group, with descriptions of a new genus, Azospirillum gen. nov., and two species, Azospirillum lipoferum (beijerinck) comb. nov. and Azospirillum brasilense sp. nov. Can J Microbiol 24, 967-980.

Xie, C.-H. \& Yokota, A. (2005). Azospirillum oryzae sp. nov., a nitrogen-fixing bacterium isolated from the roots of the rice plant Oryza sativa. Int J Syst Evol Microbiol 55, 1435-1438. 